\title{
Deceleration of the electron transfer reaction in the photosynthetic reaction centre as a manifestation of its structure fluctuations
}

\author{
V. N. Kharkyanen', Yu. M. Barabash', N. M. Berezetskaya', M. V. Olenchuk', \\ P. P. Knox ${ }^{2}$, L. N. Christophorov ${ }^{1,3}$ \\ ${ }^{1}$ Institute of Physics, NAS of Ukraine \\ 46 Nauki Ave., Kyiv, Ukraine, 03039 \\ ${ }^{2}$ M. V. Lomonosov Moscow State University \\ GSP-1, Leninskie Gory, Moscow, Russian Federation, 119991 \\ ${ }^{3}$ M. M. Bogolyubov Institute for Theoretical Physics, NAS of Ukraine \\ 14-b Metrologichna Str., Kyiv, Ukraine, 03680
}

kharkyanen@iop.kiev.ua; knox@biophys.msu.ru; 1christ@bitp.kiev.ua

\begin{abstract}
Aim. To extract information on the nature of protein structural relaxation from the kinetics of electron transfer reaction in the photosynthetic reaction centre ( $R C)$. Methods. The kinetic curves obtained by absorption spectroscopy are processed by a maximum entropy method to get the spectrum of relaxation times. Results. A series of distinctive peaks of this spectrum in the interval from $0.1 \mathrm{~s}$ to hundreds of seconds is revealed. With the time of exposure of the sample to actinic light increasing, the positions of the peak maxima grow linearly. Conclusions. Theoretical analysis of these results reveals the formation of several structural states of the RC protein. Remarkably, in each of these states the slow reaction kinetics follow the same fractional power law that reflects the glass-like properties of the protein.
\end{abstract}

Keywords: protein structure relaxation, nonexponential kinetics, time-dependent reaction barrier, primary reactions of photosynthesis.

Introduction. Biochemical reactions with the participation of biological macromolecules (proteins mostly) are usually known to demonstrate "deviations from simple behaviour" [1].

Even "simple" reactions of monomolecular type, for instance, binding of ligands or one-electron oxidation/reduction, are featured by complicated and

(C) Institute of Molecular Biology and Genetics NAS of Ukraine, 2010 evidently non-exponential kinetics. Besides, thermal behaviour of the reaction rate constants is non-Arrhenius. Both factors testify that description of these reactions in the framework of standard chemical kinetics is insufficient.

In recent decades the deviations are generally explained as a result of direct impact of structural movements of protein and its conformational fluctuations on the reaction. The fluctuations change 
more or less the characteristics of an active centre, promote the evolution of a reaction barrier, etc. The time spectrum of fluctuations can be extremely wide up to 10 orders - which causes high dispersion of the reaction rate "constants" (characteristic times).

A classic example (which is still one of the main reactions while investigating a regulatory role of slow structural motions of protein) is the reverse binding of photodetached $\mathrm{CO}$ ligand to macromolecule of myoglobin, the kinetics of which is registered in the interval from submicroseconds to seconds and longer [2, 3]. A similar situation is also notable for the reactions of electron transfer in the pigment-protein complex of the photosynthetic reaction centre (RC) $[4,5]$.

Naturally, such significant deceleration of elementary biochemical reactions complicates their simulation, as it almost eliminates the possibility of computer simulations of MD-type even in case of well-determined static structure of protein. It is also unreal to monitor thoroughly its dynamics during the experiment. The latter is usually performed to register only the kinetics of the main reaction (i.e. the state of ligand, electron or any other "substrate" of the reaction).

Therefore, all suggested mechanisms of structural regulation are of hidden nature and so far cannot be directly proven. The only criterion of adequacy of models is their capability of reproducing observed fine details of the respective reaction, and, more seldom, their predicting capability for independent experiments. It should be noted that the quality of both experimental data and methods of their analysis becomes critical.

The results of numerous works, devoted to the reactions in complicated relaxing environment $[6,7]$, including those of proteins, may be summarized as follows. First, the motion along conformational degrees of freedom is diffusive, while the description of reactions in the framework of two-three discrete conformations ("active-inactive" type, etc.) is insufficient (see e.g. [8, 9]). Second, this diffusion is of non-standard character, related to hierarchical "tier" structure of the protein energy landscape [10] and to peculiar hierarchy of freedom degrees, when faster ones "limit" motion along slower $[11,12]$. Usually, it comes] to a time-dependent diffusion coefficient for the variable determining the reaction barrier. In its turn, this causes the observed re- laxation dependences of "stretched exponential" type $\left(\exp \left(-t / \tau_{0}\right)^{\beta}\right.$, where $\left.\beta<1\right)$ or power decrease $\left(t^{\alpha}, \alpha>0\right)$, which is typical for glass-like materials similar in this sense to proteins [7, 13-15].

In general, this problem is far from trustworthy conclusions on the mechanisms of structural regulation. Therefore, the non-trivial evidences of the impact of conformational fluctuations on the kinetics of electron transfer between the cofactors of reaction centres, analyzed in this work, may be quite informative.

Materials and Methods The photosynthetic RC of bacteria and reactions of electron transfer in it are one of the most studied biophysical systems (for instance, see [16]). The scheme of primary oxidation-reduction reactions in $\mathrm{RC}$, isolated from bacteria $R b$. sphaeroides, may be presented as follows:

$$
P Q_{A} Q_{B} \leftrightarrows P^{+} Q_{A}^{-} Q_{B} \leftrightarrows P^{+} Q_{A} Q_{B}^{-},
$$

where $P, Q_{A}, Q_{B}$ are cofactors, built in RC protein $(P-$ primary donor of the electron, presented by a dimer of bacteriochlorophyll; $Q_{A}, Q_{B}$ - primary and secondary acceptors of quinone nature, respectively). The light-activated photodonor at first very quickly (in $\sim 100 \mathrm{ps}$ ) transfers the electron to the primary quinone, and then the charge separation is stabilized by electron transfer from $Q_{A}$ to $Q_{B}$. If there is no further photochemical channel the electronin response to RC pulse excitation returns to the oxidized photodonor in $\sim 1 \mathrm{~s}$ at physiological conditions; this very reaction will be a subject offurther analysis as it is the most liable to the impact of structural fluctuations [17]. Since the intermediate state $P^{+} Q A^{-} Q B$ of scheme (1) is negligibly populated, we considered a simplified scheme:

$$
P Q_{B} \stackrel{h v}{\leftrightarrows} P^{+} Q_{B}^{-},
$$

It should be taken into account that the return of the electron via $Q_{A}$ depends on the reaction barrier determined by the difference in the electron free energies at $Q_{A}$ and $Q_{B}[18]$. The rate of direct reaction is proportional to the intensity of actinic light. It is noteworthy that contrary to the majority of studies on $\mathrm{RC}$ reactions in response to impulse excitation, we study the consequences of continuous excitation of specific duration and intensity, as only in this case the 
effects of RC conformational rearrangements are especially significant (for details see [19-21] ).

In the scheme (2) the kinetics is mostly registered by the methods of differential absorption spectroscopy, as the system has a stable optic marker - an absorption band at $865 \mathrm{~nm}$, which bleaches at the donor $P$ photooxidation of. The absorption changes in this band, taken with the opposite sign and properly normalized, are a quantitative indicator of the charge separation (i.e. they present the population of $P^{+} Q_{B}^{-}$ state). The hardware - software complex for registration of these changes in time and the method of obtaining preparations of isolated $\mathrm{RC}$ are described in [22]. Finally, the analysis of kinetics of recombination ( distribution of relaxation times) was performed using a version of the maximum entropy method (MEM) developed by us (for details see [22]).

Results Fig.1 presents a typical series of experimental kinetic curves, reflecting the process of photoseparation of charges and subsequent recombination according to the scheme (2). In this case the intensity of exciting light was the same for all the curves, but the exposure time $t_{\exp }$ was in the range from 10 to $100 \mathrm{~s}$. The following distinctive features of the process are clearly evident. In the beginning of photoactivation there is fast oxidation of the donor (reduction of the acceptor), accompanied by additional and relatively slow charge separation (until the moment of switching off the exciting light). The latter is related to structural adjustment of RC protein (in $Q_{B}$ environment mainly) to a new charge state [19]. The same is the reason of evident deceleration of the electron return after switching off the light and increase of $t_{\exp }$.

For further detailed analysis of the curves, their relaxation (decreasing) part was expanded in a spectrum of relaxation times using MEM which is much more reliable method than approximation with a small number of exponents [22]:

$$
n(t)=n(0) \int_{0}^{\infty} g(\tau) e^{-t / \tau} \mathrm{d} \tau \quad\left(\int_{0}^{\infty} g(\tau) \mathrm{d} \tau=1\right)
$$

where $n(t)$ in this case is the population of state with the electron transferred to $Q_{B}$. A typical result of this procedure is presented in Fig. 2 for exposure $t_{\exp }=60 \mathrm{~s}$, where five peaks $g_{i}(\tau)$ are well separated with the

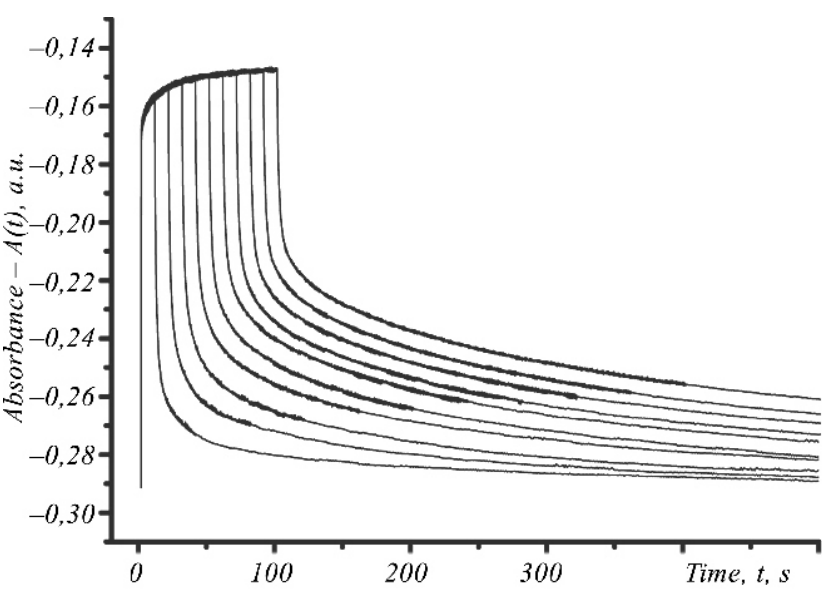

Fig. 1. Kinetics of absorbance changes for different exposure times: $t_{\exp }=10,20,30 \ldots 100 \mathrm{~s}$, light intensity $I=0.375 \mathrm{~mW} / \mathrm{cm}^{2}$ (a.u. apparatus units)

maxima at $\tau \approx 0.1 \mathrm{~s}, 1 \mathrm{~s}, 5 \mathrm{~s}, 50 \mathrm{~s}$, and $450 \mathrm{~s}$, the area for which is proportional to the number of RCs with the photoexcited electron recombining with the time characteristic for the given peak. The relaxation parts of all the curves presented in Fig. 1 were subjected to the same expansion. As a result, the recombination curves after photoexcitation of intensity $I$ during $t_{\text {exp }}$ can be presented as a sum of contributions from each of obtained peaks:

$$
n\left(t ; t_{\exp }\right)=n\left(0 ; t_{\exp }\right) \sum_{i=1}^{5} \eta_{i}\left(t ; t_{\exp }\right) \quad\left(\sum_{i=1}^{5} \eta_{i}\left(0 ; t_{\exp }\right)=1\right) .
$$

Fig.3 shows the components $\eta_{i}(t, 60 \mathrm{~s})$ of relaxation curve $n(t, 60 \mathrm{~s})$, restored in accordance with the expression

$$
\eta_{i}\left(t ; t_{\exp }\right)=\int_{0}^{\infty} g_{i}\left(\tau ; t_{\exp }\right) e^{-t / \tau} \mathrm{d} \tau,
$$

where $g_{i}\left(\tau ; t_{\text {exp }}\right)$ - separate peaks in the distribution of relaxation times.

The result, which we would like to highlight in this work, is presented in Fig.4, $a$, where deceleration of the relaxation at increasing $t_{\exp }$ is illustrated by the shift of the fifth peak towards even higher values, this rise being rather well linearly approximated.

$$
\tau_{5}^{\max }\left(t_{\exp }\right)=\tau_{0}^{(5)}+v_{5}^{*} \cdot t_{\exp } .
$$




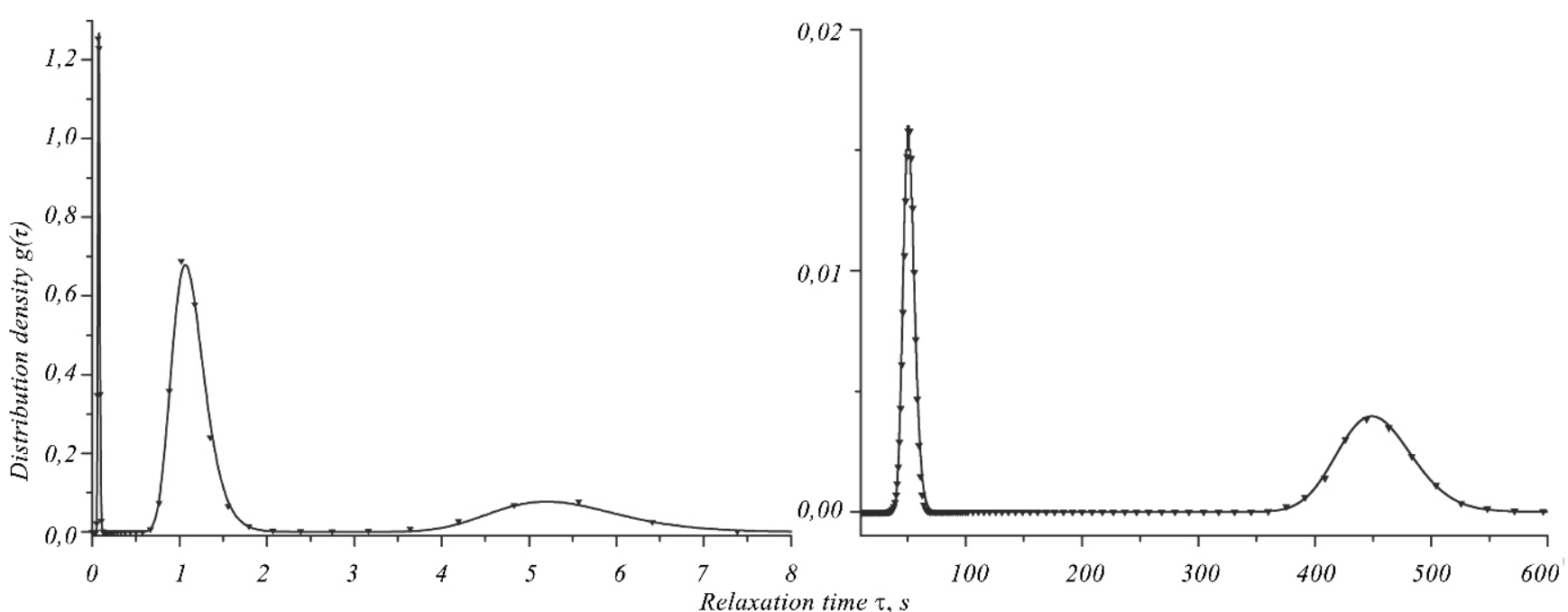

Fig. 2. Spectrum of relaxation times $g(\tau)$ (see Eq. $(3)) ; t_{\exp }=60 \mathrm{~s}$

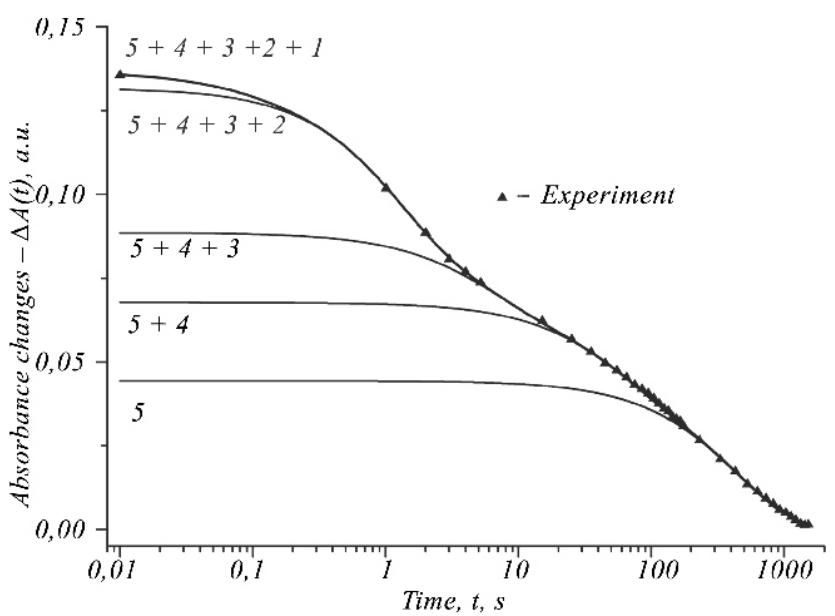

Fig. 3. Kinetics of decay of absorption changes after $60 \mathrm{~s}$ exposure. Curve 5 corresponds to the fifth component, curve $5+4$ - to the sum of 5 th and 4 th, etc.

A similar effect is observed for the $3^{\text {rd }}, 4^{\text {th }}$ peaks and even for "immovable" first and second ones, though with very little $v^{*}{ }_{1,2}$. The latter is natural as it is well known that the first peak corresponds to the $\mathrm{RC}$ fraction, inevitably present in the samples, in which the secondary acceptor is absent or inactive, and therefore, reflects fast recombination from $Q_{A}$ [16]. The second one is related to the $\mathrm{RC}$ portion, which has not undergone structural changes under the charge photoseparation, and reflects a relaxation response of $\mathrm{RC}$ to pulse excitation (see also "Discussion").

Let us make an important assumption that even at the relaxation stage, i.e. after switching off the light, the "instant" recombination time $\tau_{\mathrm{r}}^{(\mathrm{i})}\left(t ; t_{\text {exp }}\right)$ also follows linear law

$$
\tau_{r}^{(i)}\left(t ; t_{\exp }\right)=\tau_{i}^{\max }\left(t_{\exp }\right)+v_{i}\left(t_{\exp }\right) \cdot t .
$$

If the decay of each component $\eta_{i}\left(t ; t_{\text {exp }}\right)$ is described by equation

$$
\frac{\mathrm{d} \eta_{i}\left(t ; t_{\exp }\right)}{\mathrm{d} t}=-K_{i}\left(t ; t_{\exp }\right) \eta_{i}\left(t ; t_{\exp }\right),
$$

where the time dependence of the rate "constant" $K_{i}(t$; $\left.t_{\text {exp }}\right) \equiv 1 / \tau_{\mathrm{r}}^{(\mathrm{i})}\left(t ; t_{\text {exp }}\right)$ reflects all effects of "static" and "dynamic" disorder [6] (i.e. an impact of conformational substates and transitions between them), then the formula (6) means hyperbolic decrease of this ["]constant["] in time. The integration of the equation (7) yields:

$$
\begin{aligned}
\eta_{i}\left(t ; t_{\exp }\right)=\eta_{i}\left(0 ; t_{\exp }\right) \exp \left[-\int_{0}^{t} K_{i}\left(t^{\prime} ; t_{\exp }\right) \mathrm{d} t^{\prime}\right]= \\
=\frac{\eta_{i}\left(0 ; t_{\exp }\right)}{\left(1+\frac{v_{i}}{\tau_{i}^{\max }} t\right)^{\frac{1}{v_{i}}}} .
\end{aligned}
$$

The kinetics of this type (transforming into the exponential one only in the limit $v_{i} \rightarrow 0$ ) in protein reactions was observed as early as in $[23,24]$ on the 

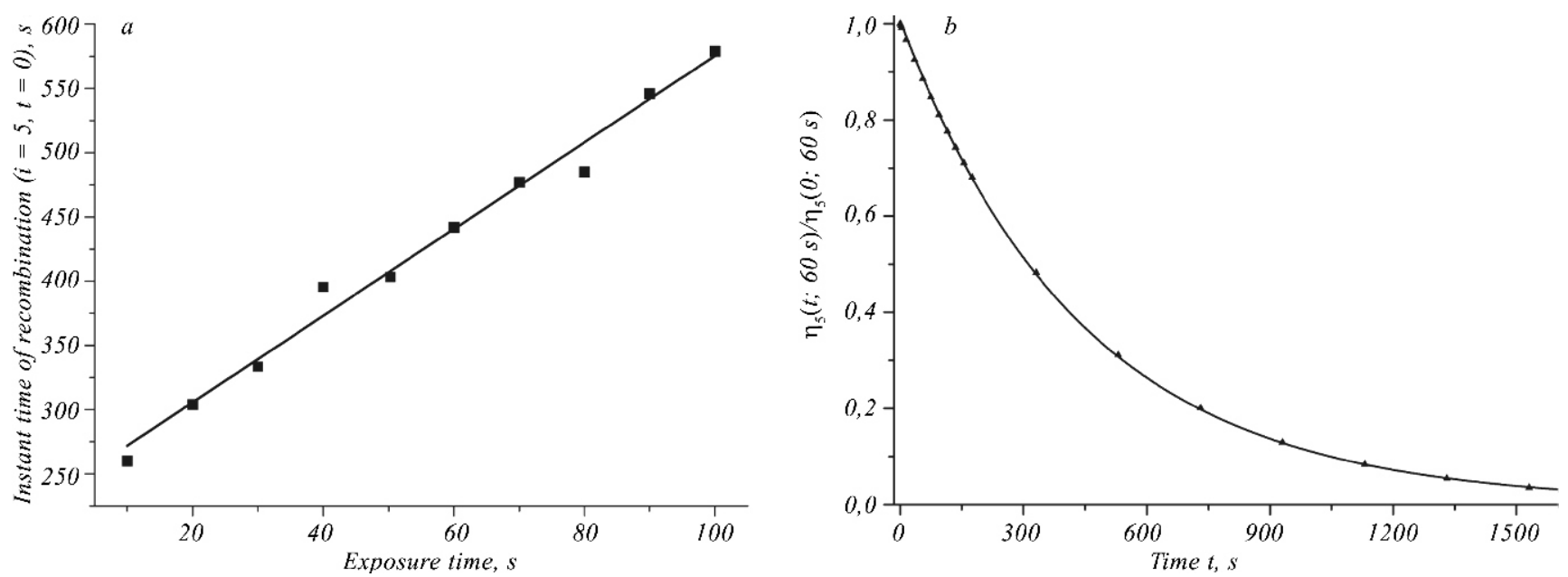

Fig. 4. Dependence of the time of recombination at its initial moment $\tau_{5}^{\max }\left(t_{\exp }\right)$ on the exposure time $(a)$ and kinetics of decay of the fifth components, restored by the fifth peak, obtained using MEM (triangles) and by formula (9) (solid line) (b)

two most popular systems - RC and MbCO (see also "Discussion").

The analytical distribution of relaxation times, corresponding to the kinetics of (8) type, is easy to find as according to $(4),\left(1 / \tau^{2}\right) g_{i}\left(\tau ; t_{e x} p\right)$ is nothing but Laplace transform $\eta_{\mathrm{i}}\left(t ; t_{\text {exp }}\right)$. The reverse transformation gives [25]:

$g_{i}\left(\tau ; t_{\text {exp }}\right)=\frac{\eta_{i}\left(0 ; t_{\text {exp }}\right)}{\Gamma\left(\frac{1}{v_{i}}\right)}\left(\frac{\tau_{i}^{\max }}{v_{i}}\right)^{\frac{1}{v_{i}}} \frac{e^{-\tau_{i}^{\max / v_{\tau} \tau}}}{\tau^{1+1 / v_{i}}}$,

where $\Gamma$ is gamma function. It should be noted that distribution (9) has one maximum at $\tau_{i}^{\max } /\left(v_{i}+1\right)$, close to $\tau_{\mathrm{i}}^{\max }$ if $v_{\mathrm{i}}<<1$. Therefore, the distribution of relaxation times, obtained from the whole relaxation curve $n\left(t ; t_{\exp }\right)$, corresponds to:

$$
\begin{gathered}
g\left(\tau ; t_{\text {exp }}\right)=\sum_{i=1}^{5} g_{i}\left(\tau ; t_{\exp }\right)= \\
=\sum_{i=1}^{5} \frac{\eta_{i}\left(0 ; t_{\text {exp }}\right)}{\Gamma\left(\frac{1}{v_{i}}\right)}\left(\frac{\tau_{i}^{\max }}{v_{i}}\right)^{\frac{1}{v_{i}}} \frac{e^{-\tau_{i}^{\max / v_{i} \tau}}}{\tau^{1+1 / v_{i}}} .
\end{gathered}
$$

Let us apply the theoretical dependence (10) to the experimental results, analyzed by MEM (shown in Fig. 2 by a solid curve). It is evident that [the] theory is in very good agreement with the experiment. The table presents the obtained parameters of all five peaks of distribution $\mathrm{g}(\tau ; 60 \mathrm{~s})$.

Good agreement is obtained also for the separate components. For instance, Fig. 4, b presents the kinetics of decay of the fifth component which is restored, on the one hand, by the last peak with maximum of $\sim 450 \mathrm{~s}$, and on the other - according to the formula (9) with corresponding parameters from the table. Finally, Fig.5 contrary to Fig. 3 presents the comparison of relaxation curve $n(t ; 60 \mathrm{~s})$, obtained experimentally, with the curve restored by the formula (3) with theoretical distribution (10). The observed evident coincidence confirms the validity of linear (hyperbolic) law of increase (decrease) of the instant recombination time (reaction rate constant) with time (6).

Similar results were obtained for all other exposures.

Finally, let us make another important remark. Under normal conditions the recombination of the electron from the secondary quinone acceptor is mainly determined by its thermoactivated transfer to the primary quinone acceptor [16], therefore, the following equation is valid

$$
K(t)=a e^{-X(t)},
$$

where $a$ is a constant; $X(t)$ - difference between free energies of the electron on primary and secondary quinone acceptors, the changes in which reflect the 
Parameters of distribution $g_{i}(\tau ; 60 s)$ of type (9) for each of the peaks of total spectrum $g(\tau ; 60 \mathrm{~s})$ obtained using MEM from kinetics of recombination

\begin{tabular}{ccccc}
\hline Peak, $i$ & $\eta_{i}(0 ; 60 s)$ & $\tau_{i}^{\max }(60 \mathrm{~s})$ & $v_{\mathrm{i}}$ \\
\hline 1 & 0,034 & 0,076 & 0,015 \\
2 & 0,32 & 1,1 & 0,03 \\
3 & 0,14 & 5,3 & 0,019 \\
4 & 0,19 & 51,2 & 0,009 \\
5 & 0,316 & 451 & 0,005 \\
\hline
\end{tabular}

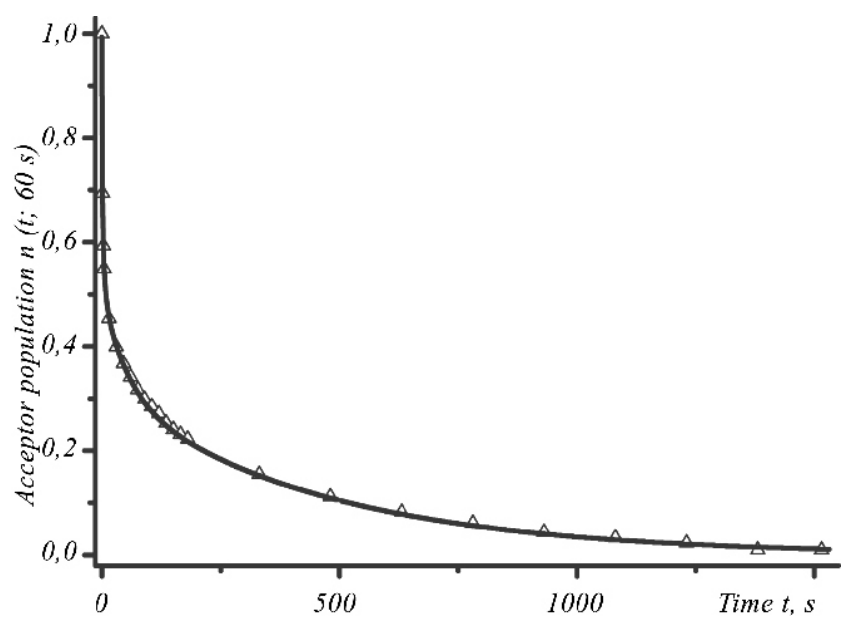

Fig. 5. Kinetics of recombination after exposure to light for $60 \mathrm{~s}$. Solid line - theory, triangles indicate the course of experimental curve

evolution of reaction barrier. From this it follows directly that the hyperbolic dependence leads to the logarithmic law of change in the reaction barrier value

$$
X(t)=\ln \left[a\left(\tau_{0}+v t\right)\right]
$$

which was also observed in some models of structural diffusion [26].

Discussion Use of kinetic curves to receive the information about structural reorganizations of $\mathrm{RC}$, caused by photoexcitation and recombination of the electron, is a non-trivial task and requires adequate methods of experimental data analysis.

The maximum entropy method (MEM), used in this work, permits to isolate specific relaxation components out of the kinetic curve of the electron recombination. As it was mentioned above, the observed component of recombination $\eta_{1}\left(t ; t_{\text {exp }}\right)$ with characteristic time $\tau_{1}{ }^{\max } \approx$
$0.1 \mathrm{~s}$ corresponds to recombination of the electron in $\mathrm{RC}$ without the secondary quinone acceptor. The rest of recombination components could be easily related to the initial differences in RC structure, unless the experimentally revealed $\mathrm{RC}$ redistributions between the components are taken into account (for details, see [22]). Supposing that these components correspond to initially identical $\mathrm{RC}$, a significant difference in their kinetics can be explained by faster structural relaxation, which occurs right after localization of the photo-mobilized electron on the secondary quinone acceptor. This relaxation should result in the formation of three RC fractions, with different structural deformations showing up as corresponding components of $\eta_{i}\left(t ; t_{\text {exp }}\right), i=3,4,5$, which have characteristic times $\tau_{3}{ }^{\max } \approx 5 \mathrm{~s}, \tau_{4}{ }^{\max } \approx 50 \mathrm{~s}, \tau_{5}{ }^{\max } \approx 450 \mathrm{~s}$ (see Fig.2), differing by orders of magnitude under exposure of $60 \mathrm{~s}$.

The relaxation processes, causing the occurrence of these states, may be considered $[11,12]$ as the relaxation of higher level and related to local rearrangements of $\mathrm{RC}$ structure close to the places of localization of separated charges. It is just this slow structural relaxation of a lower level seems to be observed in the experiment for the formed $\mathrm{RC}$ fractions. The logarithmic dependence of the reaction barrier of electron recombination, corresponding to the revealed linear dependences of the reverse recombination rate, would be logically attributed to slow non-specific relaxation of peripheral parts of macromolecule globule [7, 26], notable for the relaxation processes in glass-like matrices.

The aforesaid may be presented as a scheme (Fig. 6), where each of the four two-level (electron on donor or on acceptor) electronic schemes corresponds to its structural state. The structural state 2 corresponds to $\mathrm{RC}$ organisation with the electron on donor (i.e. it is "dark-adapted" state); after the photoexcited electron gets on the acceptor, structural changes are initiated resulting in RC transition to one of the structural states $3-5$. The $\mathrm{RC}$ in state 2 is replenished by $\mathrm{RC}$ from these fractions after recombination of the photoexcited electron. Thus, the "dark-adapted" state 2 is of dynamic nature (see also [24]). The distribution of recombination times for this structure does not depend on the photoexcitation exposure, its maximum is at $\tau_{2}{ }^{\max } \approx 1 \mathrm{~s}$, 


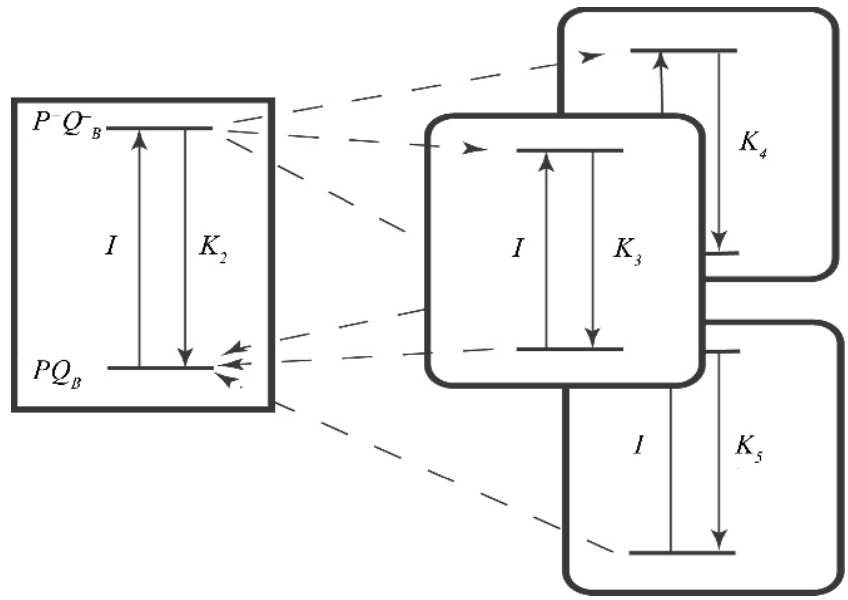

Fig. 6. Scheme of formation of structurally deformed states $3,4,5$

its shape is well described by Eq. (9). Independence of the position of peak of the "dark-adapted" state on the photoexcitation time may be explained by the fact that due to electron fast recombination, the structure remains in the initial state, corresponding to the position of the electron on the donor.

These assumptions can be partially referred to the structural state 3 , which $\tau_{3}{ }^{\max }$ weakly depends on the exposure time. The structural states 4,5 , and partially 3 , formed as a result of relaxation of higher level, continue to relax in accordance with the law (12), specific for the systems in glass-like matrix. The time for the structure to return to the "dark-adapted" state is likely to depend on "deformation depth" which results in strong dependence of $\tau_{i}^{\text {max }}$ on the exposure time for the states 4 , and especially 5 , but weak - for 3 . In other words, on the average, after recombination of the electron in states $4,5 \mathrm{RC}$ do not relax into the "dark-adapted" state before the repeated photoexcitation. The state 3 is characterized by much less recombination time and the dependence is weakly expressed. It is noteworthy that similar assumptions were previously used by us in the simulation of "light-" and "dark-adapted" RC under prolonged photoactivation [19-21].

Conclusions The experimental data obtained according to the proposed scheme of electron-conformational transitions in the RC permit to define the following stages in the photoexcitation process studied:
1. Electron transfer from the donor to the final quinone acceptor, the rate of which $K_{i}\left(0, t_{\text {exp }}\right)$ at any moment of photoexcitation $t_{\exp }$ for each RC depends on its structural state $i$.

2. Relatively fast process of RC relaxation with the electron on the acceptor from the "dark" (dynamic) structural state 2 into one of the structural states of higher level 3, 4, 5, which is supposed to reach minimum free energy of the system in times not registered in our experiment.

3. Slow processes of further relaxation of the $\mathrm{RC}$ with the electron on the acceptor and in $i$-th structural state occur in accordance with the law (12), characteristic for the systems in glass-like matrix, which is likely to correspond to relaxation of peripheral parts of the RC protein globule, accompanying a faster (local) relaxation of higher level.

It is noteworthy that the scheme, suggested in this work, is simplified and does not take into account a detailed character of RC transitions between structural states of higher level, which may be revealed at different intensity of photoexcitation. Thus, at considerably lower intensity of photoexcitation we observed the occurrence of a new structural state of the $\mathrm{RC}$ as a result of bifurcation [22], which may be related to the interaction of relaxation processes of different levels.

The work is partially performed in the framework of the project "Fundamental properties of physical systems in extreme conditions" of the Department of Physics and Astronomy of NAS of Ukraine.

В. Н. Харкянен, Ю. М. Барабаш, Н. М. Березецкая, М. В. Оленчук, П. П. Нокс, Л. Н. Христофоров

Замедление реакции переноса электрона в фотосинтетическом реакционном центре как проявление флуктуаций его структуры

Резюме

Цель. Определить характер структурной релаксации белка из анализа кинетики реакиии электрон-ного транспорта в фотосинтетическом реакиионном иентре (РЦ). Методы. Кинетические кривые, полученные методами абсорбционной спектроскопии, обрабатывали с использованием метода максимальной энтропии для получения спектра времен релаксаиии. Результаты. Обнаружен ряд характерных пиков этого спектра в интервале от 0,1 до сотен секунд. С увеличением длительности экспозиции образиа в актиничном свете поло- 
жения максимумов пиков линейно возрастают. Выводы. Из теоретического анализа результатов следует, что появляется несколько структурных состояний белкового компонента РЦ, в которых, однако, медленная кинетика реакции подчиняется одному и тому же дробно-степенному закону, отражающему стеклоподобные свойства белка.

Ключевые слова: структурная релаксация белка, неэкспоненциальная кинетика, переменный барьер реакции, первичные реакиии фотосинтеза.

В. М. Харкянен, Ю. М. Барабаш, Н. М. Березеиька, М. В. Оленчук, П. П. Нокс, Л. М. Христофоров

Уповільнення реакції перенесення электрона у фотосинтетичному реакційному центрі як прояв флуктуацій його структури

Резюме

Мета. Визначити характер структурної релаксації білка 3 аналізу кінетики реакції електронного транспорту у фотосинтетичному реакиійному иеентрі (РЦ). Методи. Кінетичні кривi, одержані з використанням абсорбиійної спектроскопії, обробляли методом максимальної ентропії для отримання спектра часів релаксації. Результати. Знайдено низку характерних піків цього спектра в интервалі від 0,1 до сотень секунд. $3 i$ збільшенням тривалості експозиції зразка в актинічному світлі положення максимумів піків лінійно зростають. Висновки. 3 теоретичного аналізу результатів випливає, щчо виникає декілька структурних станів білкового компонента РЦ, у яких, однак, повільна кінетика реакиї підпорядкована одному й тому ж дрібно-ступеневому закону, що відбиває склоподібні властивості білка.

Ключові слова: структурна релаксація білка, неекспоненційна кінетика, змінний бар 'єр реакції, первинні реакиії фотосинтезу.

\section{REFERENCES}

1. Karplus $M$. Aspects of protein reaction dynamics: Deviations from simple behavior // J. Phys. Chem.-2000.-104, N 1.P. 11-27.

2. Agmon N., Doster W., Post F. The transition from inhomogeneous to homogeneous kinetics in $\mathrm{CO}$ binding to myoglobin // Biophys. J.-1994.-66, N 5.-P. 1612-1622.

3. Jackson T. A., Lim M., Anfinrud P. A. Complex nonexponential relaxation in myoglobin after photodissociation of MbCO: measurement and analysis from 2 ps to 56 us // Chem. Phys.-1994.-180, N 2-3.-P. 131-140.

4. Goushcha A. O., Dobrovolskii A. A., Kapoustina M. T., Privalko $A$. $V$., Kharkyanen $V$. $N$. New physical phenomenon of dynamical self-organization in molecular electron transfer systems // Phys. Lett. A.-1994.-191, N 5-6.-P. 393-397.

5. Abgaryan G. A., Christophorov L. N., Goushcha A. O., Holzwarth A. R., Kharkyanen V. N., Knox P. P., Lukashev E. A. Ef- fects of mutual influence of photoinduced electron transitions and slow structural rearrangements in bacterial photosynthetic reaction centers // J. Biol. Phys.-1998.-24, N 1.-P. 1-17.

6. Zwanzig R. Rate processes with dynamic disorder // Acc. Chem. Res.-1990.-23, N 5.-P. 148-152.

7. Plonka A. Dispersive kinetics // Ann. Rep. Progr. Chem. C.2001.-97, N 1.-P. 91-147.

8. Agmon N. Conformational cycle of a single working enzyme // J. Phys.Chem. B.-2000.-104, N 32.-P. 7830-7834.

9. Christophorov L. N., Kharkyanen V. N. Discrete versus continuous schemes of conformational regulation // Chem. Phys. Res. J.-2007.-1, N 1.-P. 1-14.

10. Frauenfelder H., Wolynes P. G., Austin R. H. Biological physics // Rev. Mod. Phys.-1999.-71, N 2.-P. S419-S430.

11. Palmer R. G., Stein D. L., Abrahams E., Anderson P. W. Models of hierarchically constrained dynamics for glassy relaxation // Phys. Rev. Lett.-1984.-53, N 10.-P. 958-961.

12. Berlin Yu. A., Burin A. L., Siebbeles L. D. A., Ratner M. A. Conformationally gated rate processes in biological macromolecules // J. Phys. Chem. A.-2001.-105, N 23.-P. 56665678.

13. Frauenfelder H., Wolynes P. G. Biomolecules: Where the physics of simplicity and complexity meet // Phys. Today.1994.-47, N 2.-P. 58-64.

14. Sokolov I. M., Klafter J., Blumen A. Fractional kinetics // Phys. Today.-2002.-55, N 11.-P. 48-54.

15. Berlin Yu. A., Fisher S. F., Chekunaev N. I., Goldanskii V. I. Non-exponential non-Arrhenius relaxation in the course of CO rebinding to heme proteins // Chem. Phys.-1995.-200, N 3.-P. 369-385.

16. Hoff A. J., Deisenhofer J. Photophysics of photosynthesis. Structure and spectroscopy of reaction centers of purple bacteria // Phys. Rep.-1997.-287, N 1-2.-P. 1-247.

17. Stowell M. H. B., McPhillips T. M., Rees D. S., Soltis S., Abresh E., Feher G. Light-induced structural changes and the mechanism of electron/proton transfer in the photosynthetic reaction center // Science.-1997.-276, N 5313.-P. 812-816.

18. Okamura M. Y., Feher G. Proton transfer in reaction centers from photosynthetic bacteria // Ann. Rev. Biochem.-1992.61, N 1.-P. 861-896.

19. Barabash Yu. M., Berezetskaya N. M., Christophorov L. N., Goushcha A. O., Kharkyanen V. N. Effects of structural memory in protein reactions // J. Chem. Phys.-2002.-116, N 10.-P. 4339-4352.

20. Goushcha A. O., Manzo A. J., Scott G. W., Christophorov L. N., Knox P. P., Barabash Yu. M., Kapoustina M. T., Berezetska N. M., Kharkyanen V. N. Self-regulation phenomena applied to bacterial reaction centers. Nonequilibrium adiabatic potential: dark and light conformations revisited // Biophys. J.-2003.-84, N 2.-P. 1146-1160.

21. Christophorov L. N., Kharkyanen V. N. Synergetic mechanisms of structural regulation of the electron transfer and other reactions of biological macromolecules // Chem. Phys.2005.-319, N 1-3.-P. 330-341.

22. Lukashev E. P., Knox P. P., Rubin A. B., Olenchuk M. V., Barabash Yu. M., Berezetskaya N. M., Kharkyanen V. N. The analysis of the kinetics of dark recombination of photodivided charges in the Rhodobacter sphaeroides photosynthetic reaction centers using the method of relaxation time constant distribution // Biofizika.-2009.-54, N 3.-P. 296-301.

23. Austin R. H., Beeson K., Eisenstein L., Frauenfelder H., Gunsalus I. C., Marshall V. P. Activation energy spectrum of a biomolecule: Photodissociation of carbonmonoxy myoglobin 
at low temperatures // Phys. Rev. Lett.-1974.-32, N 8.P. 403-405.

24. Kleinfeld D., Okamura M. Y., Feher G. Electron transfer kinetics in photosynthetic reaction centers cooled to cryogenic temperatures in the charge-separated states: Evidence for light-induced structural changes // Biochemistry.-1984.-23, N 24.-P. 5780-5786.

25. Bateman H., Erdelyi A. Tables of integral transforms.-NewYork: McGraw-Hill Inc., 1954.-Vol. 1.-343 p.
26. Berlin Yu. A., Siebbeles L. D. A. Energy relaxation during thermally activated diffusion along one-dimensional chains with site disorder // Chem. Phys. Lett. -1998.-291, N 1-2.P. 85-93.

UDC 577.355

Received 11.01.10 